\title{
Pemberdayaan Usaha Mikro Kecil Aksesoris Aquarium Desa Tamanharjo Singosari Kabupaten Malang
}

\author{
Maris Kurniawati ${ }^{1}$, Rizky Lutviana ${ }^{2}$ \\ Universitas Kanjuruhan Malang ${ }^{1,2}$ \\ maris@unikama.ac.id ${ }^{1}$, lutviana.rizky@unikama.ac.id ${ }^{2}$
}

\begin{abstract}
This community service program aimed at empowering H-Fish aquarium Assesories small business to become independent and developed. A business may be considered as developed if it meets criteria such as increasing revenue, increasing product variation, efficient production, good packaging, and good management system that meets standard. In order to achieve that goal, the researcher gave sequencial trainings including training in operating and maintenance the machine production, training in packaging product and label design, training business management that meets standard and training in product variation. Besides, the researcher also helped to improve product marketing including renovating production side and building showroom to display the product to attract potential buyers. The results of this community service were increasing revenue since the product variation is increasing and the packaging was also improved to be more attractive. H-Fish Aquarium Assesories developed well because of efficient production, good business management, and wider marketing.
\end{abstract}

Keywords: Aquarium assesories; Small business; Tamanharjo; Singosari; Malang

\begin{abstract}
Abstrak
Kegiatan pemberdayaan masyarakat ini bertujuan untuk membantu mitra pengrajin aksesoris aquarium H-Fish menjadi usaha mikro yang lebih maju dan mandiri. Sebuah usaha mikro dikatakan lebih maju dan mandiri ditinjau dari beberapa indikator, antara lain peningkatan omset, bertambahnya varian produk, efisiensi proses produksi, pengemasan yang menarik, dan pelaksanaan manajemen usaha sesuai standar usaha mikro. Rangkaian kegiatan yang dilaksanakan untuk mencapai tujuan yaitu pelatihan penggunaan dan pemberian bantuan hibah penambahan alat-alat produksi aksesoris dan perlengkapan aquarium, pelatihan dan pendampingan proses pengemasan produk dan desain label produksi yang menarik, pelatihan tentang manajemen usaha yang memenuhi standar, membantu perbaikan tempat produksi yang representatif, membantu pendirian outlet sebagai sarana pemasaran produk, serta pelatihan untuk penambahan varian produk aksesoris dan perlengkapan akuarium. Saat ini omset mitra telah mengalami peningkatan karena varian produk mitra telah bertambah dan produk tampil dengan kemasan yang lebih menarik. Hasil usaha H-Fizh Accesories Aquarium sebagai mitra kegiatan juga meningkat karena didukung oleh proses produksi yang lebih efisien, pelaksanaan manajemen usaha yang lebih baik, dan pemasaran produk yang meningkat.
\end{abstract}

Kata Kunci: Accesories aquarium; Usaha mikro; Tamanharjo; Singosari; Malang 


\section{A. PENDAHULUAN}

Desa Tamanharjo merupakan desa yang berada di wilayah Kecamatan Singosari Kabupaten Malang Propinsi Jawa Timur. Secara geografis Desa dengan luas 648,968 hektar ini berbatasan dengan beberapa desa. Batas sebelah utara adalah Kelurahan Losari, Kecamatan Singosari. Batas sebelah timur adalah Desa Baturetno, Kecamatan Singosari. Sebelah selatan berbatasan dengan Desa Watugede, Kecamatan Singosari dan sebelah barat dengan Kelurahan Pagentan, Kecamatan Singosari. Desa Tamanharjo secara topografi termasuk pada kategori dataran rendah dengan ketinggian kurang lebih 511,4 meter dari permukaan laut. Secara administratif, Desa Tamanharjo terbagi atas empat dusun, yaitu Dusun Kebonagung, Dusun Damean, Dusun Gondorejo Krajan dan Dusun Gondorejo Ledok. Desa Tamanharjo juga terbagi atas 6 RW dan 46 RT. Jarak Desa Tamanharjo dari pusat pemerintahan kecamatan adalah 2,3 km dan berjarak $12 \mathrm{~km}$ dari pusat pemerintahan Kabupaten. Desa Tamanharjo dengan jumlah penduduk berkisar 7.143 jiwa, memiliki sex rasio $1,3 \%$ yang artinya setiap 1.030 jiwa penduduk perempuan terdapat 623 jiwa penduduk laki-laki (Profil Desa Tamanharjo, 2013).

Ditinjau dari mata pencaharian penduduk, penduduk di Desa Tamanharjo memiliki mata pencaharian yang beraneka ragam. Penduduk yang berprofesi sebagai petani 306 orang, buruh tani 188 orang, sopir 32 orang, pedagang 281 orang, PNS 60 orang, anggota TNI 8 orang, anggota POLRI 6 orang, peternak 42 orang, tukang 32 orang, penambang pasir 53 orang dan profesi lainnya 1.842 orang. Di Desa Tamanharjo masih terdapat kepala keluarga (KK) miskin yang masih terdaftar sebagai penerima beras miskin (raskin) sebanyak 121 KK (Profil Desa Tamanharjo, 2013). Dari kondisi ini menggambarkan bahwa masih terdapat penduduk dengan sisi kesejahteraan penduduk yang tergolong rendah.
Terkait dengan kondisi yang digambarkan di atas, salah satu misi Desa Tamanharjo dalam pembagunan adalah menumbuhkembangkan Usaha Kecil dan Menengah (UKM) (Misi 7) dan Meningkatkan pembangunan ekonomi dengan mendorong semakin tumbuh dan berkembangnya pembangunan di bidang pertanian dalam arti luas, industri, perdagangan dan pariwisata (Misi 12). Berdasarkan misi Desa Tamanharjo dapat diketahui bahwa Desa Tamanharjo benarbenar memiliki harapan untuk memajukan sektor ekonomi melalui berbagai sektor, antara lain pertanian, industri, perdagangan, pariwisata dan pengembangan UKM. Pengembangan dan pemberdayaan UKM merupakan langkah strategis dan sudah terbukti mampu menopang sektor perekonomian di saat kondisi ekonomi secara umum sedang mengalami krisis (Hapsari dkk., 2014).

Sebagai upaya menggalakkan usaha ekonomi kerakyatan melalui UKM, saat ini di Desa Tamanharjo telah ada kelompok industri kecil yang cukup menjanjikan, yaitu diantaranya: industri tempe, industri stik dan makanan ringan, pengrajin kursi, pengrajin tas dan dompet, pengrajin souvenir dan hiasan aquarium. Usaha kecil yang ada rata-rata masih berskala industri rumah tangga. Salah satu industri yang sudah berjalan adalah industri rumah tangga (home industry) yang bergerak dalam produksi perlengkapan dan hiasan aquarium. Home industry ini telah berjalan selama 7 tahun tetapi belum mampu berkembang sesuai dengan yang diharapkan. Pemilik home industry ini selanjutnya berperan sebagai mitra pada kegiatan Program Kemitraan Masyarakat (PKM).

Home industry yang memproduksi pelengkap dan aksesoris aquarium ini bernama H-Fizh Accesories Aquarium dengan pemilik bernama Lukman Hakim. H-Fizh Accesories Aquarium beralamat di Jalan Rogonoto Timur No. 182 RT 04 RW 03 Dusun Damean Desa Tamanharjo 
Kecamatan Singosari Kabupaten Malang. Aksesoris aquarium produksi H-Fizh Accesories Aquarium antara lain macammacam jenis bunga sintetis yang diberi nama: brown deasy, ganggang, grass corn, lenia flori, loving leaf, silvy, vina, coconut tree, kerang koaci dan jenis yang lain. Berikut adalah contoh aksesoris aquarium bunga sintetis yang telah diproduksi (Gambar 1.).

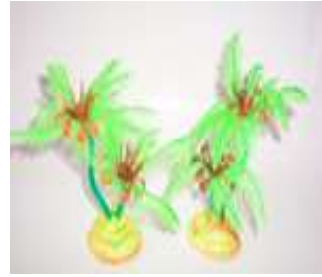

a

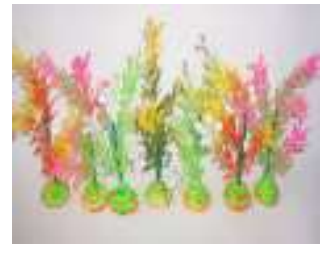

C

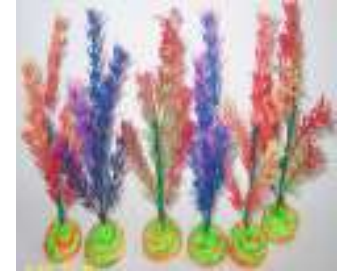

b

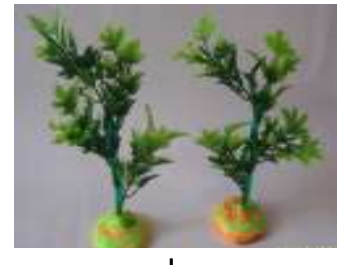

d
Gambar 1. Beberapa produk aksesoris aquarium bunga sintetis. a. Kelapa; b. Ganggang; c. Kuaci; dan d. Lenia Flori

Dilihat dari sudut pandang manajemen bisnis, industri rumah tangga ini belum memiliki perencanaan usaha jangka pendek dan jangka panjang yang jelas sehingga target dan sasaran usaha belum mengarah pada pengembangan usaha yang lebih maju. Aspek manajemen bisnis merupakan bagian dari aspek manajerial yang sangat penting dalam strategi pengembangan UKM (Sukesti dan Iriyanto, 2011). Apabila UKM belum menjalankan manajemen bisnis dengan baik maka sudah dapat dipastikan bahwa UKM akan mengalami kendala dalam pengembangannya.

H-Fizh Accesories Aquarium (label merk pada Gambar 2) saat ini belum memiliki ijin usaha yang dikeluarkan dinas industri dan perdagangan Kabupaten Malang. Manajemen keuangan dan pembukuan yang digunakan mitra juga belum menggunakan standar akuntansi untuk UMKM dan sering kali tidak dilakukan pencatatan laporan keuangan. Manajemen pengelolaan produksi masih berorientasi pada pesanan produk oleh customer dan belum mampu melakukan produksi yang mengarah pada stok produk. Hal ini berakibat pada lemahnya fungsi pemasaran. Mitra belum memiliki strategi pemasaran, sehingga pangsa pasar masih terbatas rata-rata di seputar Malang dan sebagian di wilayah Surabaya.

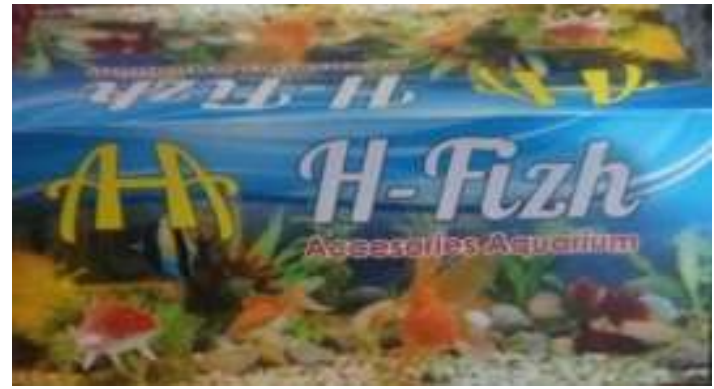

Gambar 2. Label merk H-Fizh Accesories Aquarium

Kurangnya permodalan usaha mitra untuk pengembangan dan ekspansi usaha juga menjadi kendala untuk memajukan usaha yang telah ada. Hal ini disebabkan oleh lemahnya networking dengan instansi atau lembaga terkait baik lembaga pemerintah atau swasta. Kurangnya motivasi bisnis terkait pengembangan usaha berdampak pada kegiatan usaha berjalan stagnan, sehingga belum terlihat adanya upaya untuk pengembangan menuju skala usaha yang lebih besar. Ditambah lagi dengan tempat usaha relatif sederhana dan terbatas sehingga menjadi kendala dalam kegiatan produksi.

Permintaan pasar akan produk perlengkapan dan aksesoris aquarium yang diproduksi mitra sesungguhnya cukup banyak akan tetapi ada beberapa kendala yang menyebabkan permintaan pasar belum mampu terpenuhi secara maksimal. Kendala tersebut adalah kurangnya tenaga kerja sehingga produksi belum bisa dilakukan secara continue. Tenaga kerja merupakan bagian dari sumberdaya manusia (SDM) yang masih memegang 
peran kunci untuk mengembangkan sebuah UKM (Karsidi, 2007). Peralatan produksi juga terbatas sehingga proses produksi perlu waktu yang lama. Pengemasan dan pelabelan yang kurang menarik menyebabkan harga produk dinilai kurang maksimal (Gambar 3).

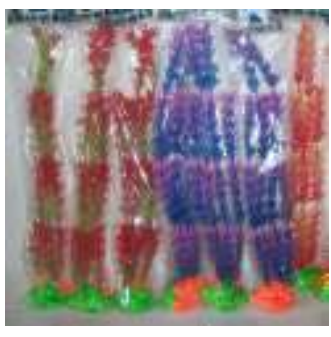

a

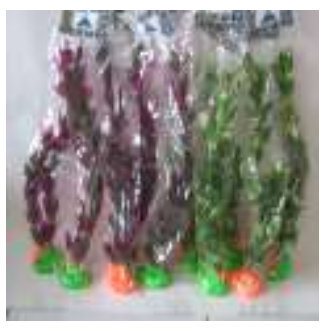

b
Gambar 3. Pengemasan produk. a. Pengemasan bunga rangkai ganggang; b. Pengemasan bunga rangkai deasy

Tempat produksi milik mitra yang kurang representatif membawa dampak pada pengembangan usaha (Gambar 4). Untuk melakukan penambahan tenaga kerja diperlukan tempat yang lebih leluasa untuk melakukan proses produksi. Mitra juga belum memiliki showroom untuk menyimpan dan mendisplay produknya. Produk jadi, setengah jadi dan bahan belum jadi semua masih tersimpan di tempat yang sama, sehingga kurang menarik saat ada customer yang berkunjung langsung ke empat produksi.

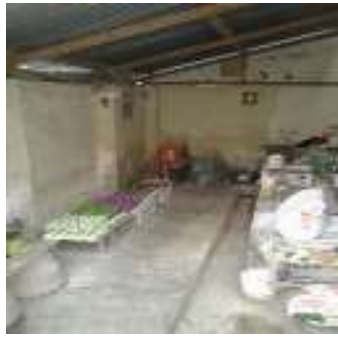

a

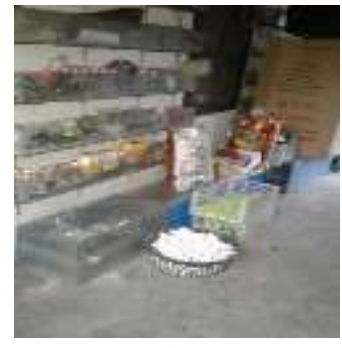

b
Gambar 4. Tempat produksi dan penyimpanan produk milik mitra. a. Tempat produksi; b. Tempat penyimpanan produk.

Sebuah ekspansi usaha juga memerlukan strategi pemasaran yang tepat. Selain display produk langsung, diperlukan upaya membuka peluang pasar dengan membuka pemasaran secara online. Seiring dengan perkembangan teknologi informasi memasuki revolusi teknologi 4.0 diperlukan upaya terobosan yang dapat mengikuti jaman. Promosi dan pemasaran online adalah upaya untuk mengembangkan usaha. Akan tetapi selama ini mitra masih tergantung dengan pemasaran konvensional. Melalui program PKM diharapkan pengabdi dapat melakukan proses sharing pengetahuan dan alih tehnologi sehingga UKM mitra dapat berkembang seperti yang diharapkan. Berkembangnya UKM mitra maka terbukalah peluang lowongan pekerjaan baru dengan harapan dapat membantu mengurangi angka kemiskinan sebanyak 121 KK yang masih ada di Desa Tamanharjo.

\section{B. PELAKSANAAN DAN METODE}

Deskripsi metode pelaksanaan dalam melaksanakan solusi yang ditawarkan adalah sebagai berikut:

\section{Pelatihan penggunaan dan pemberian bantuan hibah penambahan alat-alat produksi aksesoris dan perlengkapan aquarium}

Saat ini mitra sesungguhnya telah memiliki alat produksi berupa kuas konvensional sehingga hanya mampu menghasilkan produk dalam kapasitas yang kecil. Kuantitas produk yang ada belum mampu memenuhi permintaan customer. Guna meningkatkan kapasitas produksi usaha mitra, langkah solusi yang ditawarkan adalah memberikan bantuan hibah penambahan alat produksi pengecatan berbasis teknologi tepat guna (spray gun) sehingga proses produksi dapat dilakukan lebih efisien. Untuk memproduksi penyaring ikan diperlukan mesin jahit untuk menjahit jaring ikan dan ruber untuk alat cetak. 
2. Pelatihan dan pendampingan proses pengemasan produk dan desain label produksi yang menarik.

Dengan adanya label produksi konsumen tidak salah memilih produk yang lebih baik dan tidak dapat ditiru oleh kompetitor dan dapat menunjukkan identitas produk sehingga lebih mudah diingat bagi konsumen. Label produksi perlu didesain semenarik mungkin. Produk yang dapat diterima pasar akan lebih mudah untuk berkembang. Dalam label tertera nama produk dan informasi tentang identitas produk yang meliputi nama produsen dan nama produk, alamat dan nomor kontak produsen.

\section{Pelatihan tentang manajemen keuangan} seperti laporan keuangan usaha yang memenuhi standar akutansi UKM.

Laporan keuangan merupakan satu bagian dari manajemen keuangan. Laporan keuangan perlu dikelola sesuai dengan standar akuntansi UKM. Laporan keuangan yang baik dapat mendukung pengembangan usaha karena dapat digunakan sebagai dasar untuk mengambil keputusan dalam sebuah usaha. Permasalahan yang dihadapi mitra adalah penyusunan laporan keuangan yang kurang rapi dan sering kali tidak dilakukan pencatatan saat melakukan transaksi usaha. Solusi yang ditawarkan pada mitra adalah memberikan pelatihan dan pendampingan pembuatan laporan keuangan terutama selama pelaksanaan program PKM dan selanjutnya diharapkan dapat diteruskan setelah program PKM berakhir.

\section{Membantu perbaikan tempat produksi yang representatif.}

Produksi merupakan proses vital dalam sebuah usaha bisnis. Akan tetapi tempat produksi yang telah ada memiliki ukuran yang relatif kecil. Perlu ada upaya untuk penambahan kapasitas tempat produksi yang menunjang upaya proses peningkatan kuantitas produk. Mitra memerlukan perbaikan tempat produksi yang cukup memadai yaitu dengan menambahkan ukuran luas ruang produksi, sehingga cukup leluasa, nyaman dan memungkinkan untuk menambahkan kapasitas produksi.

\section{Membantu pendirian outlet sebagai} sarana pemasaran produk.

Saat ini mitra belum memiliki outlet untuk sarana pemasaran hasil produksi. Outlet juga dapat berfungsi sebagai sarana promosi untuk hasil produksi kelompok usaha masyarakat sekitar. Fungsi lain dari outlet adalah sebagai prasarana menyimpan stok produksi untuk tujuan perluasan pangsa pasar sehingga mitra tidak hanya mengandalkan sistem pesanan dari konsumen yang ada sebelumnya. Solusi yang ditawarkan bagi permasalahan ini adalah dengan membantu mendirikan sebuah outlet di lahan sekitar tempat produksi dengan sistem bantuan finansial sebesar $50 \%$ dari total biaya yang diperlukan untuk mendirikan sebuah outlet ukuran 3 × 2 meter persegi, sebuah etalase kue, sebuah meja dan kursi. Bantuan pendirian outlet dilakukan dengan sharing program antara tim pengabdi dengan mitra.

\section{Penambahan dan pelatihan varian produk aksesoris dan perlengkapan akuarium.}

Tambahan varian produk yang ingin segera diproduksi mitra adalah berbagai miniatur yang terbuat dari semen dan alat cetak ruber, serta penyaring ikan. Pelatihan dan pendampingan untuk menciptakan produk baru yang bisa diterima pasar, seperti miniatur air terjun, tebing dan jembatan berbahan dasar semen, serta pembuatan penyaring ikan akan dilaksanakan pada program ini.

\section{HASIL DAN PEMBAHASAN}

Program Kemitraan Masyarakat (PKM) untuk Kelompok Pengrajin Aksesoris Aquarium Desa Tamanharjo 
Singosari Kabupaten Malang dilaksanakan sebagai salah satu bentuk pelaksanaan Tri Dharma Perguruan Tinggi di bidang Pengabdian Masyarakat (abdimas). PKM untuk Kelompok Pengrajin Aksesoris Aquarium Desa Tamanharjo ini dilaksanakan dengan menerapkan paradigma yang bersifat komprehensif, problem solving, bermakna, tuntas dan berkelanjutan dengan sasaran adalah masyarakat yang produktif secara ekonomis, akan tetapi masih menghadapi berbagai kendala untuk mengembangkan produksi dan usahanya. Dikatakan demikian karena sebelum pelaksanaan program PKM kelompok mitra sudah menjalankan usahanya sekian lama, tetapi belum bisa dikatakan berkembang seperti yang diharapkan.

Selain menjalankan usahanya, kelompok mitra banyak menghadapi kendala dan masalah. Guna membantu kelompok mitra mengatasi masalahnya, dilakukan beberapa program yang dirasakan sangat pokok. Program yang telah dilaksanakan antara lain: 1) Pelatihan penggunaan dan pemberian bantuan hibah penambahan alat-alat produksi aksesoris dan perlengkapan aquarium; 2) Pelatihan dan pendampingan proses pengemasan produk dan desain label produksi yang menarik; 3) Pelatihan tentang manajemen keuangan seperti laporan keuangan usaha yang memenuhi standar akutansi UKM; 4) Pelatihan dan pendampingan dalam membuat media promosi dan strategi pemasaran online; 5) Membantu perbaikan tempat produksi yang representatif; 6) Penambahan dan pelatihan varian produk aksesoris dan perlengkapan akuarium; dan 7) Membantu pendirian outlet sebagai sarana pemasaran produk. Berikut adalah uraian kegiatan program yang telah dilaksanakan bersama dengan mitra.

1. Pelatihan penggunaan dan pemberian bantuan hibah penambahan alat-alat produksi aksesoris dan perlengkapan aquarium
Kegiatan produksi dapat berjalan dengan efisien apabila didukung oleh faktor produksi diantaranya peralatan usaha. Hibah bantuan alat yang berikan antara lain berupa kompresor dan spet untuk pengecatan, serta rankaian alat pembuat serokan ikan. Kompresor dan spet untuk pengecatan penting bagi mitra karena proses pengecatan selama ini hanya mengandalkan pengecatan secara manual menggunakan kuas. Bagian yang dicat adalah bagian dasar aksesoris bunga akuarium yang terbuat dari semen dan berfungsi sebagai pemberat hiasan bunga ketika dimasukkan air dalam aquarium. Mitra menyebut bagian ini dengan istilah dasaran bunga. Adanya dasaran maka bunga hias aquarium tetap dalam posisi bagian dasar aquarium dan tidak mengapung saat aquarium diisi dengan air.

Sebelum diberikan alat bantu pengecatan, mitra melakukan proses pengecatan dasaran memerlukan waktu 2 jam untuk mengecat 300 buah dasaran. Saat ini, dengan alat bantu pengecatan maka proses pengecatan 600 buah dasaran hanya memerlukan waktu kurang dari 30 menit saja. Waktu yang ada dapat dipergunakan mitra untuk merangkai bunga dan membuat produk aksesoris yang lain. Alat produksi merupakan perangkat teknis (technoware) sebagai bagian dari komponen teknologi yang penting untuk pengembangan UKM (Setiarso, 2006).

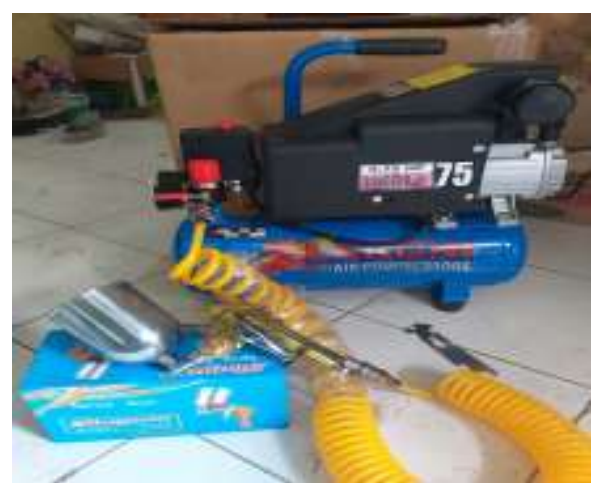

Gambar 5. Kompresor dan spet untuk pengecatan

Alat berikutnya yang diterima mitra adalah rankaian alat pembuat serokan ikan. 
Alat ini dirancang bersama dengan mitra. Alat pembuat serokan tersusun atas mal pencetak, meja plat sebagai alas pencetak, dan bor listrik. Mal pencetak berfungsi untuk template kawat serokan sehingga berbentuk seperti yang diharapkan. Bentuk mal biasanya bulat dan segi empat tergantung fungsi serokan yang akan diproduksi. Meja plat berfungsi untuk alas pencetak sekaligus tempat melekatnya mal pencetak sehingga tidak bergeser-geser. Bor listrik berfungsi untuk memilin kawat gagang serokan. Alat pembuat serokan belum tersedia di pasaran sehingga harus didesain dan dibuat sendiri bersama mitra.

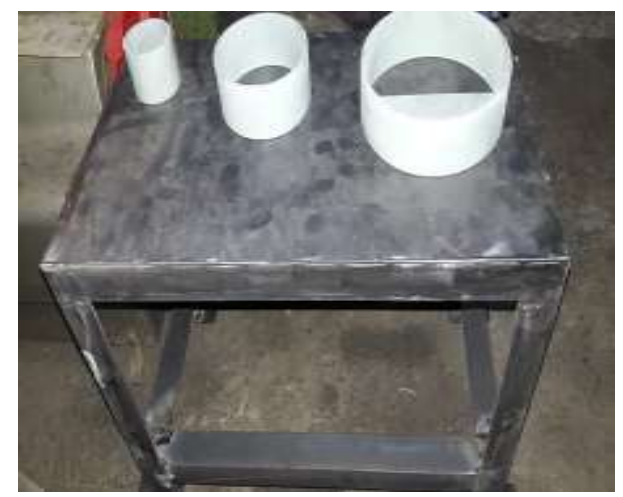

Gambar 6. Rangkaian alat pembuat serokan

2. Pelatihan dan pendampingan proses pengemasan produk dan desain label produksi yang menarik

Pertama kali konsumen melihat suatu produk, hal pertama yang menyebabkan konsumen tertarik adalah kemasan. Dari ketertarikan konsumen terhadap kemasan maka akan berlanjut ke hal lain seperti merk, bahan, manfaat, model atau desain dan hal-hal lain terkait produk. Kemasan harus rapi dan menarik, sehingga konsumen tertarik untuk membeli meskipun awalnya terkadang tidak memerlukannya. Kemasan juga harus dibuat dari bahan yang mampu melindungi produk sehingga tidak mudah kotor atau rusak sebelum sampai ke tangan konsumen. Label produksi dapat menunjukkan identitas produk sehingga lebih mudah diingat bagi konsumen. Label produksi perlu didesain semenarik mungkin sesuai standar dan dapat memenuhi keinginan pasar dan konsumen. Produk yang dapat diterima pasar akan lebih mudah untuk berkembang. Dalam label aksesoris aquarium biasanya tertera nama produk, gambar produk, nama produsen dan nomor surat ijin usaha jika ada.

Sebelum dilakukan program PKM, kemasan produk mitra terkesan biasa saja karena kemasan berasal dari bahan plastik tipis yang mudah lecek dan kotor. Kemasan yang sangat sederhana ini berdampak pada proses penjualan produk di pasaran menjadi lambat karena produk terkesan kurang menarik. Pada program PKM ini, mitra diberikan arahan untuk meningkatkan kualitas kemasan. Kemasan plastik yang dipilih terbuat dari bahan lebih tebal, mengkilat, dan tidak mudah lecek. Laporan hasil penjualan menunjukkan produk lebih cepat terjual dan mendapatkan apresiasi positif dari customer.

\section{Pelatihan tentang manajemen keuangan} seperti laporan keuangan usaha yang memenuhi standar akutansi UKM

Materi yang disampaikan saat pemberian materi manajemen keuangan yaitu empat aspek yang perlu diperhatikan dalam pengelolaan keuangan usaha yaitu sumber pendanaan, perencanaan keuangan, manajemen pemasukan dan pengeluaran. Pengembangan manajemen keuangan pada kegiatan pengabdian ini lebih menekankan pada proses pembukuan keuangan sederhana. Pelatihan pembukuan keuangan sederhana disajikan dengan memberikan contoh transaksi yang terjadi pada suatu usaha dan kemudian peserta pelatihan diminta untuk melakukan pencatatan pada lembar kerja pelatihan. Dari pelatihan ini diharapkan mitra dapat mempraktekkan sendiri berbagai transaksi yang terjadi.

Sebelum kegiatan PKM dilaksanakan, mitra hampir tidak pernah melakukan pencatatan transaksi yang sudah dilakukan, sehingga tidak tercatat besarnya modal, pemasukan, pengeluaran, dan 
keuntungan yang diperoleh. Pembukuan sederhana yang sampaikan melalui kegiatan PKM ini memudahkan mitra dalam mencatat setiap transaksi yang dilakukan. Saat ini mitra dapat mengetahui secara pasti besaran omset yang diperoleh tiap bulan, pengeluaran modal usaha yang harus disediakan, dan besarnya keuntungan yang diperoleh tiap bulan. Mitra sangat bersyukur bahwa ternyata ada peningkatan omset penjualan setiap bulan sebesar 1 juta rupiah. Selain itu mitra juga dapat melakukan analisa keuangan yang sangat berguna bagi pengembangan produksi dan mewujudkan penambahan varian produk usaha.

\section{Membantu perbaikan tempat produksi yang representatif}

Ruang produksi didesain sesuai dengan kebutuhan mitra. Ruang usaha dibangun di belakang rumah sekaligus merupakan partisipasi mitra dalam pelaksanaan program PKM ini. Ruang usaha mitra dibangun dengan luas bangunan $3 \times 5$ meter persegi dengan rancangan ruang yang diperuntukkan sebagai tempat produksi, tempat stok barang dan stok produk. Di dalam ruang produksi dilengkapi dengan papan cetak, rak penyimpan bahan baku dan lemari penyimpan produk. Berikut adalah gambar proses pembangunan ruang produksi hingga siap digunakan.

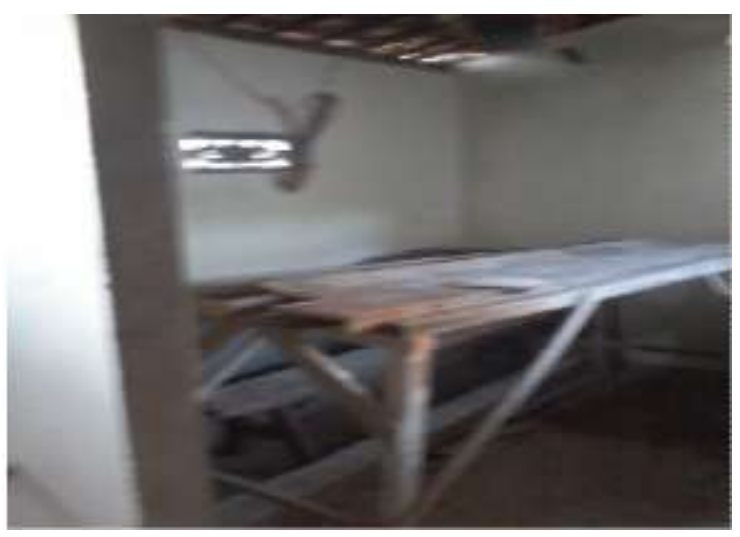

Gambar 6. Ruang produksi mitra
5. Penambahan dan pelatihan varian produk aksesoris dan perlengkapan akuarium

Variasi produk mitra sebelumnya adalah jenis rangkaian bunga yang diberi nama bunga rangkai dan bunga rambat, dengan dua jenis ukuran masing-masing kecil dan besar. Saat ini mitra telah melakukan penambahan varian produk model bunga rangkai besar, dekor berbentuk tebing, rumah, dan goa, serta mulai merintis untuk menambah varian produk serokan.

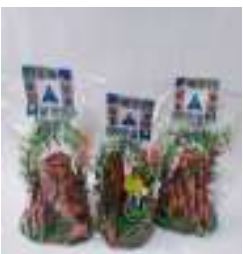

a.

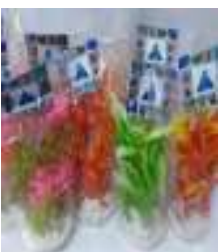

b.

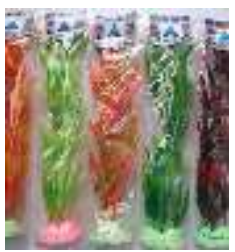

c.
Gambar 7. Varian produk baru yang diproduksi mitra

\section{Membantu pendirian outlet sebagai} sarana pemasaran produk.

Bangunan outlet penting sekali untuk mengembangkan suatu usaha. Keberadaan outlet bermanfaat sebagai bentuk komunikasi terhadap konsumen. Konsumen dapat mengetahui bahwa dilokasi berdirinya outlet tersebut konsumen dapat memperoleh produk yang suatu saat dibutuhkan. Sehingga adanya outlet juga berperan sebagai sarana promosi produk.

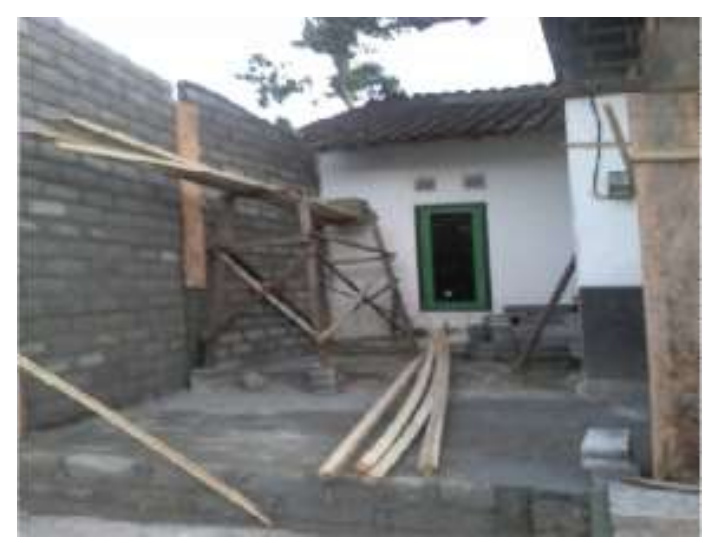

Gambar 8. Proses pembangunan outlet 
Mitra sangat berterimakasih kepada tim abdimas Universitas Kanjuruhan Malang karena harapannya untuk memiliki bangunan tempat usaha telah terwujud. Selama ini tempat usaha adalah ruang tamu mitra. Dengan adanya outlet, pelanggan lebih mudah mencari lokasi sehingga lebih banyak lagi pelanggan yang datang. Keberadaan outlet juga membuat pelanggan lebih nyaman sehingga pelanggan mendapatkan kepuasan tersendiri. Pelanggan yang puas seringkali akan merekomendasikan pada calon pelanggan yang lain. Dengan demikian pasar semakin luas sehingga dapat meningkatkan omset dan keuntungan bagi mitra. Hal ini sesuai dengan prinsip menjalankan usaha, bahwa seorang pengusaha tidak boleh menyia-nyiakan jerih payah pelanggannya untuk bisa sampai di tempat usaha. Pengorbanan pelanggan harus diimbangi dengan pelayanan prima dan kepuasan pelangan.

\section{PENUTUP}

\section{SIMPULAN}

Upaya pemberdayaan masyarakat tehadap usaha mikro H-Fish Accesories Aquarium dilakukan melalui proses pendampingan dan kerjasama bersama mitra sehingga menghasilkan kinerja yang lebih baik untuk pengembangan usaha mikro tersebut. Langkah yang ditempuh sebagai upaya pemberdayaan adalah mendorong terjadinya partisipasi mitra usaha mikro yang bersifat buttom up sehingga membawa dampak yang signifikan terhadap kemajuan sebuah usaha mikro.

\section{SARAN}

Pendampingan pada usaha mikro sebaiknya dilaksanakan secara berkesi- nambungan. Kegiatan pendampingan terhadap mitra tidak hanya berhenti hingga kegiatan selesai, akan tetapi perlu upaya lanjut untuk mewujudkan usaha mikro betul-betul menjadi usaha yang maju dan mandiri.

\section{UCAPAN TERIMA KASIH}

Ucapan terimakasih disampaikan kepada Kementrian Riset, Teknologi, dan Pendidikan Tinggi yang telah memberikan hibah Pengabdian kepada Masyarakat Skim Program Kemitraan Masyarakat (PKM), sehingga program pengabdian ini dapat terlaksana dengan baik.

\section{E. DAFTAR PUSTAKA}

Anonimous, 2013, Desa Tamanharjo

Kecamatan Singosari, Profil Desa

Tamanharjo,

https://desatamanharjo.wordpress.c om/profil/

Anonimous, 2013, Desa Tamanharjo Kecamatan Singosari, Wirausaha Desa Tamanharjo, https://desatamanharjo.wordpress.co m/potensi-sumber-daya/wirausaha.

Hapsari, P.P., Hakim, A. dan Soeaidy, S. 2014. Pengaruh Pertumbuhan Usaha Kecil Menengah (UKM) terhadap Pertumbuhan Ekonomi Daerah (Studi di Pemerintah Kota Batu). Wacana. 17(2): 88-96.

Karsidi, R. 2007. Pemberdayaan Masyarakat untuk Usaha Kecil dan Mikro (Pengalaman Empiris di Wilayah Surakarta Jawa Tengah). Jurnal Penyuluhan. Vol 3(2): 136145. 
Setiarso, B. 2006. Pengelolaan Pengetahuan (KnowledgeManagement) dan Modal Intelektual (Intelectual Capital) untuk Pemberdayaan UKM. Prosiding Konferensi Nasional Teknologi Informasi \& Komunikasi untuk Indonesia. Institute Teknologi Bandung. Hal. 187-191.
Sukesti, F. dan Iriyanto, S. 2011. Pemberdayaan UKM: Meningkatkan Komoditas Unggulan Ekspor UKM Dalam Rangka Pengembangan Ekonomi Daerah (Studi pada UKM di Jawa Tengah). Seminar Nasional Ilmu Ekonomi Terapan. Fakultas Ekonomi UNIMUS. hal. 86-92. 